University of Nebraska - Lincoln

DigitalCommons@University of Nebraska - Lincoln

Faculty Papers and Publications in Animal

Science

Animal Science Department

January 1962

SIRE EVALUATION FROM FIVE-MONTH DAUGHTER RECORDS

L. Dale Van Vleck

University of Nebraska-Lincoln, dvan-vleck1@unl.edu

Follow this and additional works at: https://digitalcommons.unl.edu/animalscifacpub

Part of the Animal Sciences Commons

Van Vleck, L. Dale, "SIRE EVALUATION FROM FIVE-MONTH DAUGHTER RECORDS" (1962). Faculty Papers and Publications in Animal Science. 320.

https://digitalcommons.unl.edu/animalscifacpub/320

This Article is brought to you for free and open access by the Animal Science Department at DigitalCommons@University of Nebraska - Lincoln. It has been accepted for inclusion in Faculty Papers and Publications in Animal Science by an authorized administrator of DigitalCommons@University of Nebraska - Lincoln. 
L. D. Van Vleck. 1962. Sire Evaluation from Five-Month Daughter Records. Journal of Animal Science 21:633-638

Abstract: The chief advantages of sire evaluation based on five-month daughter records are: 1 . Genetic progress is inversely proportional to the turnover rate in testing bulls so that if this interval is shortened by $10 \%$, the rate of genetic progress will be increased by $11 \%$. The turnover period can be shortened with the use of 5 -month records from about 50 months to 45 months-a decrease of $10 \%$ in time. 2. Genetic progress is also related to how many top bulls are saved and how many poor ones are culled out of all those sampled. In other words, the more bulls tested with the same number saved for use, then the faster the progress which can be made. The shorter length of time which bulls have to be saved with five-month record evaluation can allow up to 10\% more bulls to be tested with the same physical layout. 3. Returning a superior sire to service 5-6 months earlier will allow an increased service life for those sires. This could increase the service period by $15 \%$ and would also reduce the overhead costs to the stud as well as allow the dairyman the services of a superior bull for a few extra months. Some problems to be solved to enable bull studs to make practical use of five-month records are: 1 . Suitable mature equivalent factors must be determined for all breeds for five-month records. 2. Breed averages for five-month records must be established. 3. The regression of daughter records on stablemate averages must be estimated. 4. Estimates of variance and covariance components used in the procedures must be confirmed from larger numbers of observations. 5. The importance of differential persistency between sire groups should be investigated.

Copyright $\odot 1962$ American Society of Animal Science. Used by permission. 


\title{
SIRE EVALUATION FROM FIVE-MONTH DAUGHTER RECORDS
}

\author{
L. D. VAN Vleck \\ Cornell University, Ithaca, New York
}

M ANY current reports have indicated high genetic correlations between part lactation records and complete records. Recent research with part records has been accomplished in many countries, Hickman (1957, 1960) in Canada; Searle (1961a, b, c) in New Zealand; Mahadevan (1951), O'Conner and Stewart (1958), Rendel et al. (1959) in Great Britain; Dassart (1954) in Italy; Jöst (1959), Kliesch and Hoffer (1954) in Germany; and in the United States Madden, et al. (1956, 1959), Madden et al. (1955), Lamb and McGilliard (1959, 1960a, b), and Van Vleck and Henderson $(1961 b, c, d, g)$. The first widespread practical application of these results to evaluation of sires used in artificial insemination (AI) has been in New Zealand, Stitchberry (personal communication, 1961). There, due to seasonal freshening and the large number of young sires sampled per year, the New Zealand Dairy board plans to evaluate young sires used artificially in many herds on the basis of 1,2 , and 3 month milk and fat yield of their daughters. The New Zealand system of having all cows freshen in the spring will then allow the use of the selected young sires a full year earlier than if selection was based on complete lactation records.
This paper, however, presents the results of an evaluation of sires used artificially in New York on the basis of part records of their daughters.

\section{Data}

The 150-day records of all AI daughters which calved in New York between December, 1959 and August, 1960, inclusive, and which were available in the New York dairy records processing center were used. These records were corrected for age at freshening by factors taken from a study by Van Vleck and Henderson (1961a) based on Holstein records. As will be discussed later, such age factors may not be appropriate.

Comparisons were made between evaluations based on these records and evaluations based on $2 x, M . E$. complete records of other daughters of the same AI sires. The 305-day M.E. factors were those used in the New York dairy records processing center.

\section{Methods of Evaluation}

The future daughter performances of $\mathrm{AI}$ sires were estimated from the following equa-

TABLE 1. DHIA AND AI BREED AVERAGES FOR THE SEPTEMBER, 1961 305-DAY AND 150-DAY SIRE EVALUATION

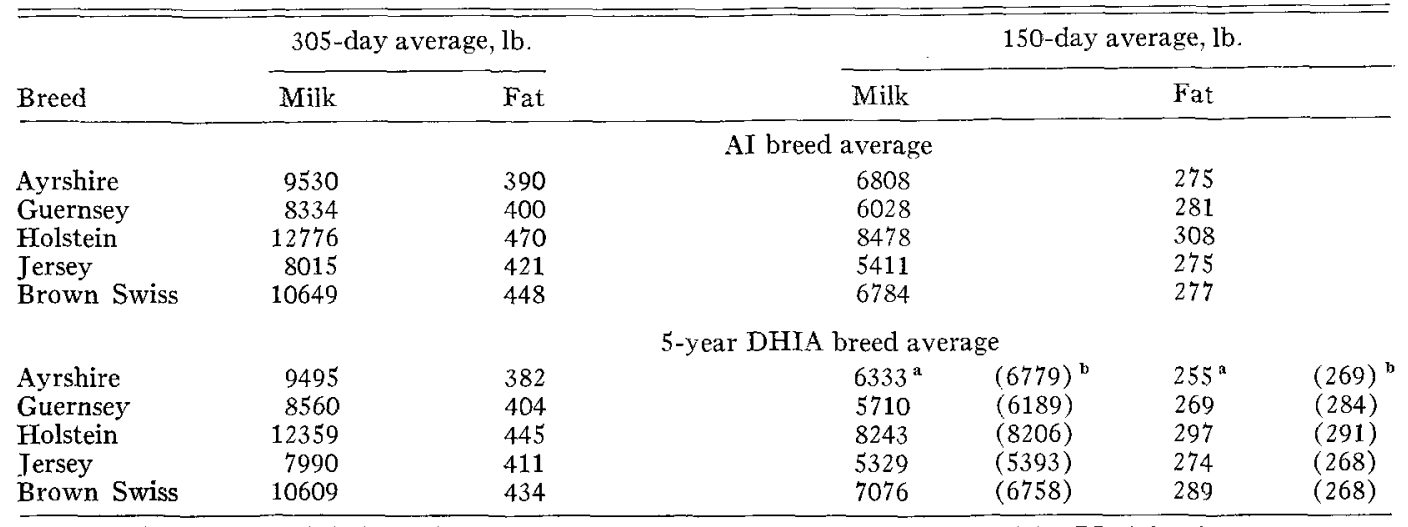

" The 5-year 150-day DHIA breed average was estimated as 0.667 times the 5-year 305-day DHIA breed average.

$b$ The 5-year 150-day average was estimated as the ratio of the 150-day to the 305 -day AI breed average times the 5-year 305-day DHIA breed average (the alternate 5-year 150-day DHIA breed average). 
tions where $\mathbf{n}$ is either the number of part or complete records:

1. Breeding value for 305-day yield

a. From 305-day records: have been collected for less than one year. It must be estimated from available data. The study of Van Vleck and Henderson (1961f) showed that the ratio of 150-day to 305-day

$$
\mathrm{EBV}_{305}=\mathrm{AI}_{305}+\frac{\mathrm{n}}{\mathrm{n}+16.66}\left[\mathrm{D}_{305}-0.9\left(\mathrm{SM}_{305}-\mathrm{DHIA}_{305}\right)-\mathrm{AI}_{305}\right]
$$

where: $\mathrm{AI}_{305}=305$ day $\mathrm{AI}$ breed average for AI daughters with records in the current report (September, 1961), $\mathbf{D}_{305}=305$-day daughter average,

$0.9=$ regression coefficient for the regression of a daughter record on the adjusted stablemate average,

$\mathrm{SM}_{305}=305$-day adjusted stablemate average (Henderson et al. 1954), and

DHIA $_{305}=305$-day 5-year DHIA breed average.

b. From 150-day records: milk yield for Holsteins was 0.667. Estimates of the 150-day DHIA breed average were made by multiplication of this factor by the 305-day DHIA 5-year breed average for all breeds. The ratio between the AI 150-day and 305-day averages, however, indicated that the former ratio is not appropriate for all breeds. Table 1 presents the AI and DHIA 305-day and 150-day breed averages for both milk and fat which were used in the preceding EBV equations. Alternate 150-day 5-year DHIA averages were estimated by multiplying the ratio of the 150-day AI average to the 305day $\mathrm{AI}$ average by the 305-day DHIA 5-year breed averages. These values are given in brackets in the appropriate columns of table 1.

$$
\mathrm{EBV}_{305}=\mathrm{AI}_{305}+\frac{1.55 \mathrm{n}}{\mathrm{n}+16.79}\left[\mathrm{D}_{150}-0.9\left(\mathrm{SM}_{150}-\mathrm{DHTA}_{150}\right)-\mathrm{AI}_{150}\right]
$$

where: $D_{150}=150$ day daughter average,

$\mathrm{SM}_{150}=150$-day adjusted stablemate average,

DHIA $_{150}=150$-day 5-year DHIA breed average, and

$\mathrm{AI}_{150}=150$-day $\mathrm{AI}$ breed average for AI daughters with records in the current report.

2. Breeding value for 150 day yield-from 150-day records:

\section{Results}

One criterion which can be used to judge the effectiveness of 150-day records is how many sires have at least 20150 -day daughter records without having 20 with 305-day records. The number of such bulls is given in table 2 for various numbers of daughter records. Three sires appeared in the Ayrshire breed, 3 in the Guernsey, and 17 in the Hol-

$$
\mathrm{EBV}_{150}=\mathrm{AI}_{150}+\frac{\mathbf{n}}{\mathrm{n}+\mathbf{1 6 . 7 9}}\left[\mathrm{D}_{150}-0.9\left(\mathrm{SM}_{150}-\mathrm{DHIA} \mathrm{A}_{150}\right)-\mathrm{AI}_{150}\right]
$$

The justification for these equations and the parameters used in them can be found in Henderson et al. (1954), Henderson (1956), Heidhues et al. (1961), and Van Vleck and Henderson (1961e, h).

Several points of possible inaccuracy have already become evident. The regression coefficient of 0.9 is appropriate for 305-day records but has not been estimated for part records in New York. Evidence from New Zealand (Searle, 1961c) indicates that it would be nearly the same for 150-day records as for 305-day records.

The other point which is much more likely to cause lack of accuracy is the estimate of the 150-day, 5-year DHIA breed average. This is unavailable since the 150 -day records stein. No other breeds contributed additional sires.

A second and more important criterion would be to determine whether any superior sires were discovered earlier or whether inferior sires could be sold earlier. The results of this classification appear in table 3. Two of the three Ayrshire bulls were in the top classification-their daughters averaging more than $300 \mathrm{lb}$. of milk above their stablemates. The average 305-day EBV for these two bulls was $10,219 \mathrm{lb}$. of milk and $412.1 \mathrm{lb}$. of fat or $724 \mathrm{lb}$. of milk and $30 \mathrm{lb}$. of fat above the DHIA breed average. These EBV's were computed using the alternate 150-day 5-year DHIA average. One of these bulls was already 
TABLE 2. NUMBER OF BULLS IN VARIOUS CLASSES BASED ON NUMBER OF 150DAY DAUGHTER RECORDS WHEN LESS THAN 20 305-DAY DAUGHTER RECORDS WERE AVAILABLE PER SIRE

\begin{tabular}{lccccc}
\hline $\begin{array}{l}\text { Number } \\
\text { of } 150 \text {-day } \\
\text { daughter } \\
\text { records }=\mathrm{N}\end{array}$ & $\begin{array}{c}\text { Ayr- } \\
\text { shire }\end{array}$ & $\begin{array}{c}\text { Guern- } \\
\text { sey }\end{array}$ & $\begin{array}{c}\text { Hol- } \\
\text { stein }\end{array}$ & $\begin{array}{c}\text { Brown } \\
\text { Swiss }\end{array}$ & $\begin{array}{c}\text { Guern- } \\
\text { sey }\end{array}$ \\
\hline $30>\mathrm{N}=20$ & 1 & 2 & 6 & 0 & 0 \\
$40>\mathrm{N}=30$ & 0 & 0 & 3 & 0 & 0 \\
$50>\mathrm{N}=40$ & 1 & 1 & 0 & 0 & 0 \\
$\mathrm{~N}=50$ & 1 & 0 & 8 & 0 & 0 \\
\hline
\end{tabular}

in service but ordinarily would not have been. The other bulls were gone.

One of the Guernsey bulls fell into the high level and one into the next lower level. The EBV of the high level bull was $200 \mathrm{lb}$. of milk and $5 \mathrm{lb}$. of fat above the breed average. The other bull showed an EBV of $100 \mathrm{lb}$. of milk and $16 \mathrm{lb}$. of fat above breed average but was not returned to service. It is of interest to note that a brother of this bull was returned to service based on 14 150-day daughter records which were $800 \mathrm{lb}$. of milk and $49 \mathrm{lb}$. of fat above their stablemates.

How do the 150-day evaluations compare with 305-day evaluations? This is a question which must be answered favorably before much reliance can be put on such evaluations. The genetic correlations of about 0.9 estimated by Van Vleck and Henderson (1961c, e) and Searle (1961c) indicate that the evaluations will be nearly the same. In actual practice, high correlations between 150-day and 305- day daughter evaluations would be desirable to substantiate the other research.

The computed correlations between 305-day and 150-day evaluations are shown in table 4. The correlations were computed for sires having more than 10 daughters in each group, more than 20 in each, and for Holstein sires having more than 100 and more than 200 daughters in each group. It should be remembered that these sires are different from those discussed earlier which had 20 daughters with 150-day records and less than 20 305-day records with the exception of the correlations with 10 daughter records in each group. It would be expected that the correlations would increase as the number of daughter records in each group increases. This increase does occur and for the Holstein sires approaches the theoretical limit of about 0.9 when more than 200 daughters are represented in each length of record group.

It can be seen from the table that using the alternate 150-day DHIA breed average increases the correlation between EBV's based on 150-day and on 305-day records. This is generally true except for the Guernsey breed. The correlations for the Guernsey sire groups are very low which indicate some technical difficulty may be involved. Age factors may be at fault.

The otherwise high correlations indicate that selection on the basis of 150 -day records does a satisfactory job of also selecting for 305-day yield. It must be emphasized that daughters having 150-day records did not also

TABLE 3. NUMBER OF BULLS IN VARIOUS CLASSES BASED ON DIFFERENCE OF 150-DAY DAUGHTER MILK AVERAGE FROM THEIR 150-DAY STABLEMATE MILK AVERAGES WHEN THE BULLS DO NOT HAVE 20 305-DAY DAUGHTER RECORDS AND DO HAVE AT LEAST 20 150-DAY DAUGHTER RECORDS ${ }^{\circ}$

\begin{tabular}{|c|c|c|c|c|c|c|c|c|c|}
\hline \multirow{2}{*}{$\begin{array}{c}\text { Average } \\
\text { 150-day stable- } \\
\text { mate difference=X } \\
\text { Milk (lb.) }\end{array}$} & \multirow{2}{*}{$\begin{array}{l}\text { No. } \\
\text { bulls }\end{array}$} & \multicolumn{2}{|c|}{$\begin{array}{c}\text { Average } 150 \text {-day stable- } \\
\text { mate difference, } 1 \mathrm{~b} \text {. }\end{array}$} & \multicolumn{2}{|c|}{$\begin{array}{l}\text { Average } 305- \\
\text { day EBV, }{ }^{\circ} \text { lb. }\end{array}$} & \multicolumn{2}{|c|}{$\begin{array}{l}\text { Average } 150- \\
\text { day } \mathrm{EBV}, \mathrm{lb} \text {. }\end{array}$} & \multicolumn{2}{|c|}{$\begin{array}{l}\text { Average 150- } \\
\text { day ME av., 1b. }\end{array}$} \\
\hline & & Milk & Fat & Milk & Fat & Milk & Fat & Milk & Fat \\
\hline & \multicolumn{9}{|c|}{ Ayrshire } \\
\hline $\begin{array}{l}-300 \leq \mathrm{X}<-100 \\
300 \leq \mathrm{X}\end{array}$ & $\begin{array}{l}1 \\
2\end{array}$ & $\begin{array}{r}-124 \\
732\end{array}$ & $\begin{array}{r}0.0 \\
27.5\end{array}$ & $\begin{array}{r}9349 \\
10219\end{array}$ & $\begin{array}{l}383.6 \\
412.1\end{array}$ & $\begin{array}{l}6691 \\
7252\end{array}$ & $\begin{array}{l}270.9 \\
289.3\end{array}$ & $\begin{array}{l}6634 \\
7554\end{array}$ & $\begin{array}{l}274.0 \\
305.5\end{array}$ \\
\hline & \multicolumn{9}{|c|}{ Guernsey } \\
\hline $\begin{aligned}-100 & \leq \mathrm{X}<100 \\
100 & \leq \mathrm{X}<300 \\
300 & \leq \mathrm{X}\end{aligned}$ & $\begin{array}{l}1 \\
1 \\
1\end{array}$ & $\begin{array}{r}12 \\
151 \\
317\end{array}$ & $\begin{array}{r}12.0 \\
16.0 \\
6.0\end{array}$ & $\begin{array}{l}8445 \\
8655 \\
8761\end{array}$ & $\begin{array}{l}410.5 \\
419.8 \\
408.8\end{array}$ & $\begin{array}{l}6099 \\
6235 \\
6303\end{array}$ & $\begin{array}{l}287.8 \\
293.8 \\
286.7\end{array}$ & $\begin{array}{l}5786 \\
6117 \\
6583\end{array}$ & $\begin{array}{l}271.0 \\
289.0 \\
300.0\end{array}$ \\
\hline & \multicolumn{9}{|c|}{ Molstein } \\
\hline $\begin{array}{l}x<-300 \\
-100 \leq \mathrm{X}<100 \\
-300 \leq \mathrm{X}<-100 \\
100 \leq \mathrm{X}<300 \\
300 \leq \mathrm{X}\end{array}$ & $\begin{array}{l}5 \\
3 \\
2 \\
4 \\
3\end{array}$ & $\begin{array}{r}-637 \\
-240 \\
-\quad 68 \\
189 \\
532\end{array}$ & $\begin{array}{r}-19.0 \\
-\quad 1.7 \\
-\quad 4.0 \\
-\quad 2.8 \\
14.3\end{array}$ & $\begin{array}{l}11901 \\
12102 \\
12413 \\
12728 \\
13127\end{array}$ & $\begin{array}{l}436.2 \\
445.9 \\
446.2 \\
453.1 \\
469.3\end{array}$ & $\begin{array}{l}7914 \\
8043 \\
8244 \\
8447 \\
8704\end{array}$ & $\begin{array}{l}286.2 \\
292.5 \\
292.7 \\
297.1 \\
307.5\end{array}$ & $\begin{array}{l}7903 \\
8280 \\
8540 \\
8796 \\
9029\end{array}$ & $\begin{array}{l}289.8 \\
306.0 \\
305.5 \\
308.5 \\
321.7\end{array}$ \\
\hline
\end{tabular}

a Values given are averages of the sire-group averages.

b EBV's were estimated using the alternate 150-day 5 year DHIA breed averages. The 305-day EBV's were estimated from the available 150 -day daughter records. 
TABLE 4. CORRELATIONS BETWEEN VARIOUS ESTIMATES OF BREEDING VALUE BASED ON 150-DAY AND 305-DAY DAUGHTER RECORDS

\begin{tabular}{|c|c|c|c|c|c|c|c|c|c|}
\hline Breed & No. Bulls & Milk a & Fat a & Milk $b$ & Fat b & Milk c & Fat ${ }^{c}$ & Milk d & Fat ${ }^{d}$ \\
\hline & \multicolumn{9}{|c|}{ Number of both 150 - and 305 -day records per sire group $=20$} \\
\hline $\begin{array}{l}\text { Ayrshire } \\
\text { Guernsey } \\
\text { Holstein } \\
\text { Jersey } \\
\text { Brown Swiss }\end{array}$ & $\begin{array}{r}9 \\
17 \\
114 \\
11 \\
7\end{array}$ & $\begin{array}{l}0.63 \\
0.19 \\
0.67 \\
0.87 \\
0.83\end{array}$ & $\begin{array}{l}0.30 \\
0.35 \\
0.59 \\
0.70 \\
0.84\end{array}$ & $\begin{array}{l}0.67 \\
0.28 \\
0.71 \\
0.83 \\
0.85\end{array}$ & $\begin{array}{l}0.40 \\
0.39 \\
0.63 \\
0.72 \\
0.85\end{array}$ & $\begin{array}{l}0.78 \\
0.22 \\
0.71 \\
0.84 \\
0.87\end{array}$ & $\begin{array}{l}0.48 \\
0.37 \\
0.63 \\
0.70 \\
0.88\end{array}$ & $\begin{array}{l}0.61 \\
0.49 \\
0.69 \\
0.94 \\
0.90\end{array}$ & $\begin{array}{l}0.55 \\
0.63 \\
0.66 \\
0.85 \\
0.84\end{array}$ \\
\hline $\begin{array}{l}\text { Aryshire } \\
\text { Guernsey } \\
\text { Holstein } \\
\text { Jersey } \\
\text { Brown Swiss }\end{array}$ & $\begin{array}{r}19 \\
30 \\
143 \\
16 \\
14\end{array}$ & $\begin{array}{l}0.56 \\
0.34 \\
0.70 \\
0.37 \\
0.61\end{array}$ & $\begin{array}{l}\quad \text { Num } \\
0.26 \\
0.49 \\
0.55 \\
0.30 \\
0.49\end{array}$ & $\begin{array}{l}\text { th } 150- \\
0.51 \\
0.39 \\
0.69 \\
0.53 \\
0.70\end{array}$ & $\begin{array}{l}305-\mathrm{da} \\
0.26 \\
0.49 \\
0.59 \\
0.42 \\
0.62\end{array}$ & $\begin{array}{l}\text { per sire } \\
0.64 \\
0.30 \\
0.68 \\
0.51 \\
0.69\end{array}$ & $\begin{array}{c}\text { oup } \equiv 10 \\
0.36 \\
0.46 \\
0.58 \\
0.45 \\
0.57\end{array}$ & $\begin{array}{l}0.72 \\
0.61 \\
0.76 \\
0.74 \\
0.34\end{array}$ & $\begin{array}{l}0.53 \\
0.74 \\
0.68 \\
0.64 \\
0.28\end{array}$ \\
\hline Holstein & 28 & 0.84 & $\begin{array}{l}\text { Num } \\
0.76\end{array}$ & $\begin{array}{l}\text { th } 150 \text { - } \\
0.86\end{array}$ & $\begin{array}{c}305-\mathrm{da} \\
0.80\end{array}$ & $\begin{array}{c}\text { per sire } \\
0.86\end{array}$ & $\begin{array}{c}u p=100 \\
0.80\end{array}$ & 0.94 & 0.94 \\
\hline \multicolumn{10}{|c|}{ Number of both 150 - and 305 -day records per sire group $\triangleq 200$} \\
\hline
\end{tabular}

have the same lactation record in the 305-day daughter average.

Table 5 compares the 150-day and 305-day stablemate differences by level of sire. These values show in another form what the correlations exhibit in more compact form. There is good agreement, as can be seen from table 5, between the average stablemate differences for 150-day and 305-day records.

The results shown in tables $2,3,4$, and 5 illustrate the chief advantages of 150-day sire evaluations. The foremost is quicker evaluation which can result in longer service life for superior sires. The quicker turnover of sires can speed up genetic progress in two ways. The first way would be that a greater number of young sires could be tested with the same physical resources. The second is that the decreased generation interval also increases genetic progress since superior sires are replaced by even better sires at a more rapid rate.

The results also indicate several technical problems in sire evaluation based on 150-day daughter records. Two of the most important are probably: (1) the determination of appropriate long-term 150-day breed averages (this difficulty will, of course, disappear in time) and (2) the determination of suitable age factors for each breed. It is possible that effects of season, sire, and herd will be more important for 150-day records than for 305-day records in developing age factors. Some evidence suggests that different mature equivalent factors should be used for each season of freshening, Van Vleck and Henderson (1961a).
Another factor to consider is the accuracy of the variance and covariance component estimates which determine the ratios, $\frac{n}{n+16.79}$ and $\frac{1.55 \mathrm{n}}{\mathrm{n}+16.79}$. At the present time these components have been estimated from a fairly limited amount of data. Experience with variance components for 305-day records suggests, however, that these ratios will not change significantly even when estimated from larger numbers of observations.

Persistency of production may vary from sire group to sire group. If high 305-day yield is the goal, then selection on 150-day yield may penalize sires having daughters with high persistency and provide unfair advantage to sires having daughters with low persistency. The high genetic correlation between 150-day and 305-day yield, however, indicates that this is an unlikely source of error, but still it should be considered as a possible source of inaccuracy.

Still another factor has been discussed previously. That is the regression of a daughter record on her stablemate average. For 305-day records it is 0.9 as estimated from adequate data. This factor may not be much different for 150-day records, Searle (1961c).

\section{Summary}

The chief advantages of sire evaluation based on five-month daughter records are:

1. Genetic progress is inversely proportional to the turnover rate in testing bulls so that if 
TABLE 5. COMPARISON OF 150-DAY AND 305-DAY DAUGHTER DIFFERENCES FROM THEIR CORRESPONDING STABLEMATES CLASSIFIED BY AVERAGE 150-DAY DIFFERENCES FROM STABLEMATE AVERAGE WHEN EACH SIRE HAS AT LEAST 20 150-DAY AND 20 305-DAY DAUGHTER RECORDS

\begin{tabular}{|c|c|c|c|c|c|}
\hline \multirow{3}{*}{$\begin{array}{l}\text { Average 150- } \\
\text { day stablemate } \\
\text { difference=X } \\
\text { Milk, lb. }\end{array}$} & \multirow[b]{3}{*}{ No. bulls } & \multicolumn{4}{|c|}{ Average difference from stablemates, lb. } \\
\hline & & \multicolumn{2}{|c|}{ 150-day } & \multicolumn{2}{|c|}{ 305-day } \\
\hline & & Milk & Fat & Milk & Fat \\
\hline \multicolumn{6}{|c|}{ Number of both 150 - and 305 -day records in sire averages $\supseteq 20$} \\
\hline \multicolumn{6}{|c|}{ Ayrshire } \\
\hline $\mathrm{X}<-300$ & 1 & -340 & 2.0 & -624 & -3.0 \\
\hline$-300 \leq X<-100$ & 3 & -129 & -2.3 & -413 & -4.7 \\
\hline$-100 \leq X<100$ & 1 & - 9 & -5.0 & -86 & -5.0 \\
\hline $100 \leq \mathrm{X}<300$ & 4 & 216 & 9.0 & -50 & 4.0 \\
\hline \multicolumn{6}{|c|}{ Guernsey } \\
\hline $\mathrm{x}<-300$ & 2 & -520 & -13.5 & -421 & -4.0 \\
\hline$-300 \leqslant x<-100$ & 4 & -211 & -11.8 & -278 & -13.5 \\
\hline$-100 \leq \mathrm{X}<100$ & 8 & 44 & 5.4 & -371 & -10.2 \\
\hline $100 \leq \mathrm{X}<300$ & 3 & 192 & 18.0 & 267 & 25.3 \\
\hline \multicolumn{6}{|c|}{ Holstein } \\
\hline $\mathrm{X}<-300$ & 16 & -464 & -10.6 & -494 & -6.1 \\
\hline$-300 \leq \mathrm{X}<-100$ & 24 & -206 & -3.1 & -248 & 0.8 \\
\hline$-100 \leq X<100$ & 30 & -2 & 3.0 & -183 & 0.8 \\
\hline $100 \leq \mathrm{X}<300$ & 26 & 185 & 6.8 & 50 & 4.0 \\
\hline $300 \leq \mathrm{X}$ & 18 & 567 & 14.7 & 851 & 24.0 \\
\hline \multicolumn{6}{|c|}{ Jersey } \\
\hline$-300 \leq X<-100$ & 1 & -267 & 2.0 & -583 & -8.0 \\
\hline$-100 \leq X<100$ & 6 & 27 & 7.5 & -113 & 4.7 \\
\hline $100 \leq X<300$ & 3 & 197 & 7.3 & 234 & 10.3 \\
\hline $300 \leq \mathrm{X}$ & 1 & 479 & 5.0 & 571 & 11.0 \\
\hline \multicolumn{6}{|c|}{ Brown Swiss } \\
\hline$-300 \leq X<-100$ & 3 & -202 & -8.0 & -165 & \\
\hline$-100 \leq X<100$ & 2 & -22 & 7.5 & -393 & 4.5 \\
\hline $100 \leq X<300$ & 1 & 242 & 19.0 & 105 & 18.0 \\
\hline $300 \leq \mathrm{X}$ & 1 & 567 & 16.0 & 1135 & 38.0 \\
\hline
\end{tabular}

this interval is shortened by $10 \%$, the rate of genetic progress will be increased by $11 \%$. The turnover period can be shortened with the use of 5-month records from about 50 months to 45 months - a decrease of $10 \%$ in time.

2. Genetic progress is also related to how many top bulls are saved and how many poor ones are culled out of all those sampled. In other words, the more bulls tested with the same number saved for use, then the faster the progress which can be made. The shorter length of time which bulls have to be saved with five-month record evaluation can allow up to $10 \%$ more bulls to be tested with the same physical layout.

3. Returning a superior sire to service 5-6 months earlier will allow an increased service life for those sires. This could increase the service period by $15 \%$ and would also reduce the overhead costs to the stud as well as allow the dairyman the services of a superior bull for a few extra months.

Some problems to be solved to enable bull studs to make practical use of five-month records are:

1. Suitable mature equivalent factors must be determined for all breeds for five-month records.

2. Breed averages for five-month records must be established.

3 . The regression of daughter records on stablemate averages must be estimated.

4. Estimates of variance and covariance components used in the procedures must be confirmed from larger numbers of observations.

5. The importance of differential persistency between sire groups should be investigated. 


\section{Literature Cited}

Dassart, P. 1954. E possible anticiparee rendere pid accurate il progeny test nel bestiame de latte? Att. IV Riunione Biometric Society e I Riunione Associazone Genetica Italiano, Roma. March 27-28.

Heidhues, T., L. D. Van Vleck and C. R. Henderson. 1961. Actual and expected accuracy of sire proofs under the New York system of sampling bulls. Z. Tierz. Züchtungsbiol. 4:323.

Henderson, C. R. 1956. Cornell research on methods of selecting dairy sires. Proc. New Zealand Soc. An. Prod. 16:69.

Henderson, C. R., H. W. Carter and J. T. Godfrey. 1954. Use of the contemporary herd average in appraising progeny tests of dairy bulls. J. Animal Sci. 13:959.

Hickman, C. G. 1957. Production studies on experimental farms dairy herds. I. Age correction of 180day milk yield. Can. J. Animal Sci. 37:123.

Hickman, C. G. 1960. Production studies in experimental farms dairy herds. II. Usefulness of 180-day yield for culling. Can. J. Genetic Cytol. 2:189.

Jöst, H. 1959. Die Beurteilung verschiedener Färsenkurzleistungsabschnitte im Hinblick auf eine vorlaüfige Erbwertschätzung bei Bullen. Zuchtungskunde, 31:201.

Kliesch, J. and J. Hoffer. 1954. Untersuchungen uber die Möglich keit einer fröhzeitigen. Erbwertermittlung auf Grund der Färsen kurzleistung von 200 und 305 Tagen. Z. Tierz. Züchtungsbiol. 64:153.

Lamb, R. C. and L. D. McGilliard. 1959. Variables affecting the ratio of total milk produced in 305 days to monthly production. J. Dairy Sci. 42:924.

Lamb, R. C. and L. D. McGilliard. 1960a. Variables affecting ratio factors for estimating 305-day production from part lactation. J. Dairy Sci. 43:519.

Lamb, R. C. and L. D. McGilliard. 1960b. Comparison of ratio factors for extending part-time milk and fat records. J. Dairy Sci. 43:879.

Madden, D. E., J. L. Lush and L. D. McGilliard. 1955. Relations between parts of lactations and producing ability of Holstein cows. J. Dairy Sci. 38:1264.

Madden, D. E., L. D. McGilliard and N. P. Ralston. 1956. Relations between monthly test day milk production of Holstein-Friesian cows. J. Dairy Sci. 39:932.
Madden, D. E., L. D. McGilliard and N. P. Ralston. 1959. Relations between test day milk production of Holstein dairy cows. J. Dairy Sci. 42:319.

Mahadevan, P. 1951. The effect of environment and heredity on lactation. I. Milk yield, II. Persistency of lactations. J. Agr. Sci. 41:80, 89.

O'Conner, L. K. and A. Stewart. 1958. The use of 180-day records in contemporary comparisons. Rep. Prod. Div. Milk Mktg. Bd. 8:93.

Rendel, J. M., A. Robertson, A. A. Asker, S. S. Khishin and M. T. Ragab. 1957. The inheritance of milk production characteristics. J. Agr. Sci. 48:426.

Searle, S. R. 1961a. Part lactations. I. Age-correction factors for monthly milk fat yields. J. Dairy Sci. $44: 104$.

Searle, S. R. 1961b. Part lactations. II. Genetic and phenotypic studies of monthly fat yield. J. Dairy Sci. 44:282.

Searle, S. R. 1961c. Part lactations. III. Progeny testing with part lactation records. J. Dairy Sci. 44: 921.

Van Vleck, L. D. and C. R. Henderson. 1961a. Ratio factors for adjusting monthly test day data for age and season of calving and ratio factors for extending part lactation records. J. Dairy Sci. 44:1093.

Van Vleck, L. D. and C. R. Henderson. 1961b. Regression factors for extending part lactation milk records. J. Dairy Sci. 44:1085.

Van Vleck, L. D. and C. R. Henderson. 1961c. Estimates of genetic parameters of some functions of part lactation milk records. J. Dairy Sci. 44:1073.

Van Vleck, L. D. and C. R. Henderson. 1961d. Regression factors for predicting a succeeding complete lactation milk record from part lactation records. J. Dairy Sci. 44:1322.

Van Vleck, L. D. and C. R. Henderson. 1961e. The use of part lactation records in sire evaluation. J. Dairy Sci. 44:1511.

Van Vleck, L. D. and C. R. Henderson. 1961f. Extending part lactation milk records by regression ignoring herd effects. J. Dairy Sci. 44:1519.

Van Vleck, L. D. and C. R. Henderson. 1961g. Variance and covariance components in part lactation milk and fat records. J. Dairy Sci. 44:1870.

Van Vleck, L. D. and C. R. Henderson. 1961h. Utilizing both incomplete and complete daughter records in sire evaluation. J. Dairy Sci. 44:2068. 